УДК 78.071.2(477) “ХХІ”

DOI:

Ірина Гринчук, кандидат педагогічних наук, доцент кафедри музикознавства та методики музичного мистеитва факультету мистецттв

Тернопільського національного педагогічного університету імені В. Гнатюка

Марія Іздепська-Новіцька, викладач кафедри музикознавства та методики музичного мистецтвва факультету мистеитв

Тернопільського національного педагогічного університету імені В. Гнатюка

\title{
КОНЦЕРТНИЙ ТА КОНКУРСНО-ФЕСТИВАЛЬНИЙ НАПРЯМКИ У РОБОТІ З СТУДЕНТСЬКИМИ ХОРОВИМИ КОЛЕКТИВАМИ
}

Піднято проблемукомплексного підходудо роботи із студентськими хоровими колективами. Увагу зосереджено на таких компонентах як підготовка навчальних хорових колективів до участі у різних тематичних концертах, концертах-звітах та іниих мистецьких заходах, у конкурсах та фестиваляххорової музики різного рівня.

Ретроспективно представлено діяльність жіночого хору Тернопільського начіонального педагогічного університету імені В. Гнатюка у ї̈ концертному та конкурсно-фестивальному аспектах. Висвітлено та проаналізовано основні складові репертуарного списку колективу.

Ключові слова: сучасне хорове виконавство; студентський хоровий колектив; конщертна і конкурснофестивальна діяльність; хоровий репертуар.

Jim. 5.

Iryna Hrynchuk, Ph. D.(Pedagogy), Associate Professor of the Musicology and Methods of Music Art Department Ternopil Volodymyr Hnatyuk National Pedagogical University Mariya Izdepska-Novitska, Lecturer of the Musicology and Methods of Music Art Department Ternopil Volodymyr Hnatyuk National Pedagogical University

\section{CONCERT AND COMPETITION FESTIVAL VECTORS IN WORKING WITH THE STUDENT CHOIR COLLECTIVES}

The problem of the integrated approach to work with student choir collectives is raised as an important component of the process of preparation of the teachers of artistic disciplines.

Attention is focused on such components of choral activity as the training of choral groups for participation in various thematic concerts, annual concerts and other artistic events, competitions and festivals of choral music of various levels.

There has been illustrated the significance of the concert, competition and festival and repertoire aspects in work with the student choir group on the example of the female choir of the Faculty of Arts of Volodymyr Hnatyuk TNPU which is one of the first choral ensembles of the university. There have been represented the artistic directors and conductors of the given collective.

There has been observed concert and competition and festival activity of the collective, its participation in choral creative forums of city, regional levels of different levels of functioning.

There have been highlighted and analyzed the main components of the repertoire of the collective as the basis of formation of vocal and choral culture of students, their acquisition of experience of practical choral and conductor's work as the future participant or leader of the choir collective, their experience of concert and competitive activity as well.

There have been presented the rubrics of the repertoire of the collective, including works of spiritual character of foreign and Ukrainian composers, classical samples of versatile works of foreign and national choral literature, choral adaptationi of Ukrainian song heritage, popular works by contemporary artists, etc. An interesting form proved to be the creation of the so-called "choral and choreographic compositions" as a performance of choral works with the active usage of the choreographic component on the example of the contemporary popular repertoire.

It has been concluded that the combination of educational, concert and festival practice provides the integrity of the process of professional preparation of participants and future leaders of choir collectives. The process is facilitated by appropriate versatile repertoire material, which should include masterpieces of European and world choral music, highly artistic samples of domestic classical music, inexhaustible volumes of Ukrainian song heritage, samples of contemporary choral composition, interesting adaptations and arrangements of contemporary popular music.

Keywords: modern choral performance; the student choir collective; concert and competition and festival activity; choral repertoire.

процес підготовки майбутнього вчителя фахових дисциплін, які забезпечують

мистецьких дисциплін (Г. Падалка, О. Рудницька, О. Ростовський та ін.), важливе місце займає 


\section{КОНЦЕРТНИЙ ТАКОНКУРСНО-ФЕСТИВАЛЬНИЙ НАПРЯМКИ У РОБОТІ ЗСТУДЕНТСЬКИМИ ХОРОВИМИ КОЛЕКТИВАМИ}

хоровий клас, де формуються фахові компетенції щодо опанування різножанрових творів, вокальнохорові навички та основи диригування, накопичується концертний та навчальний виконавський репертуар. Наша практика засвідчує, що ефективним стає поєднання системної навчальної діяльності із підготовкою різних тематичних програм, творчих звітів хорових колективів і диригентських класів, концертних програм випускників-магістрантів [2]. Актуалізації опанованого хорового репертуару значною мірою сприяє підготовка студентського хору до участі у конкурсах та фестивалях хорової музики різного рівня (міських, обласних, регіональних, Всеукраїнських, Міжнародних) [1].

Таким чином, успішно формується навчальний, концертний, конкурсний досвід майбутніх керівників шкільних хорів, ансамблів, малих форм, а хорові студентські колективи стають своєрідною “творчою лабораторією”, часто і “творчою візитівкою” факультету, навчального мистецького закладу [4].

Мета статті - представити основні компоненти та специфіку роботи із студентськими хоровими колективами. Завдання статті висвітлити значення концертного, конкурснофестивального та репертуарного аспектів у роботі із студентським хоровим колективом на прикладі жіночого хору факультету мистецтв ТНПУ ім. В. Гнатюка.

Виклад основного матеріалу. Представимо зазначені аспекти на прикладі діяльності жіночого хору факультету мистецтв як одного із перших хорових колективів ТНПУ ім. В. Гнатюка, що був започаткований у 1980 р. [5].

Великуроль у становленні колективу, у процесі закладення основ виконавської хорової культури відіграли його наставники-диригенти. Серед них: композитор і педагог I. Пронь [5], заслужений артист України, доцент Є. Гунько (від 1984 р.) [3], Г. Місько (від 1995 р.) [4], заслужений працівник культури, доцент В. Семчишин (1998 - 2001 рр.), М. Іздепська-Новіцька (з 2003 р. по сьогодні) [2].

Розглянемо коротко історію жіночого хору в контексті концертно-конкурсної діяльності, опираючись на аналіз репертуару колективу.

Так, до репертуару жіночого хору під керуванням доцента Є. Гунька [3] входили відомі зразки хорової спадщини українських композиторів-класиків М. Лисенка, С. Людкевича (зокрема "Гагілка"), К. Данькевича ("Чорний крук у полі кряче”), М. Леонтовича, К. Стеценка та ін., які були основною навчального і концертного репертуару, звучали на урочистих заходах та концертах, у рамках творчих робіт і мистецьких дійств у стінах навчального закладу, на сценах Тернополя, на творчих зустрічах, для прикладу, у тодішньому Івано-Франківському педагогічному інституті перед українцями 3 діаспори (травень 1989 p.).

Під орудою Г. Олексін (Місько) жіночий хор збагатив свою репертуарну палітру, зокрема, репрезентував хорову творчість сучасних українських композиторів, розширив діапазон своїх концертних виступів, успішно зарекомендував себе на конкурсних хорових змаганнях, зокрема, на обласному конкурсі на здобуття премії імені С. Крушельницької, нашої славетної землячки [1;4].

Так, у IV конкурсі на здобуття премії ім. С. Крушельницької (1997р.), приуроченому до

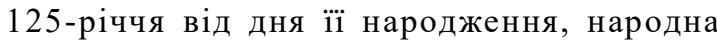
аматорська жіноча хорова капела університету отримала відзнаку Гран-прі, виконавши обов'язковий твір “Петрівочку” з камерної кантати № 1 Л. Дичко та цікавий сучасний твір американського композитора Д. Артмана "Бах і рок".

HaV конкурсіназдобугтяпреміїім. С. Крушельницької (2002 р.) народний аматорський жіночий хор був відзначений журі за інтерпретацію "Гагілки" С. Людкевича, виборов диплом II ступеня і був запрошений для участі у творчому звіті кращих аматорських та професійних колективів Тернопільщини ум. Києві [1].

За період, впродовж якого жіночий хор очолював заслужений працівник культури України, доцент В. Семчишин [2], навчальний і концертний репертуар оновився низкою творів зарубіжних та українських композиторів, зокрема, і перекладених керівником спеціально для жіночого хору. Серед них назвемо наступні: "Чи ми ще зійдемося знову?” С. Людкевича, частини 3 кантати А. Вівальді "Gloria” (чч. I,VII, IX, XI), “Слов'янський танець” А. Дворжака та ін. Зазначимо, що у цей період жіночий хор залучався до співпраці із естрадно-симфонічним оркестром Тернопільської обласної філармонії.

Як художній керівник та диригент жіночого хору, М. Іздепська-Новіцька розвинула кращі традиції попередніх керівників, зокрема, продовжила творчу працю В. Семчишина, зробивши переклад решти 5-ти хорових частин кантати А. Вівальді “Gloria” для складу жіночого хору. Концертне виконання кантати відбулося 4.06.2006 р. в Палаці культури "Березіль” у супроводі Галицького камерного оркестру та солістів - М. Іздепської-Новіцької (контральт) та заслуженої (тепер - народної) артистки України Н. Лемішки (сопрано) [2].

На сьогодні жіночий хор є міцною навчальною 


\section{КОНЦЕРТНИЙ ТАКОНКУРСНО-ФЕСТИВАЛЬНИЙ НАПРЯМКИ}

У РОБОТІ ЗСТУДЕНТСЫКИМИ ХОРОВИМИ КОЛЕКТИВАМИ

базою для навчання майбутніх учителів музичного мистецтва, відіграє значну роль у формуванні їх музичної культури, у набутті досвіду просвітницької та концертної діяльності.

Так, свій вокально-хоровий жіночий хор під орудою М. Іздепської-Новіцької презентував на III Міжнародному молодіжному фестивалі духовного співу "Кременецькі хорові вечори "Ave Maria" (Кременець, 10-11.05. 2008 р.). Впродовж фестивальних заходів, жіночий хор виступав в костелі м. Кременця, виконавши повністю кантату "Gloria” А. Вівальді в супроводі Галицького камерного оркестру [2].

У 2010 р. жіночий хор вдруге було запрошено до Кременця на V Міжнародний молодіжний фестиваль духовного співу Кременецькі хорові вечори “Ave Maria”. Хop також виступив із сольною програмою в с. Горинка Кременецького району та на заключному концерті в БК м. Кременця. Слухачі фестивалю особливо відмітили виконання “Богородице Діво” Б. Фільц.

Своєрідним підсумком творчої діяльності диригента та учасників колективу стали звітні концерти у травні 2010 р. та у червні 2011 р. Так, у програмі першого з них було представлено 12 хорових номерів, у програмі другого концерту 18 номерів, серед них 12 хорових [2].

У 2012 р. на Відкритому Свропейському фестивалі-конкурсі духовної пісні “Я там, де $\epsilon$ благословення” (Тернопіль, 27 - 29.04. 2012 р.) колектив був відзначений дипломом І ступеня. У виконанні хору прозвучали "Богородице Діво" Б. Фільц, "Хваліте Господа з небес" (фрагмент 3 Літургії) О. Кошиця, Хоровий концерт “Камо піду от лиця твого, Господи” М. Лисенка [2].

У 2014 р., конкурс змінив свій формат, провівши патріотичну мистецьку акцію за участю переможців попередніх конкурсів, зокрема i жіночого хору університету (концертмейстер С. Федик). У гала-концерті взяли участь хористи iз різних регіонів, зокрема, хор із Кривого Рогу Донецької області. Згодом, хор успішно виступив на черговому фестивалі-конкурсі духовної пісні у 2017 р., у якому прийняли участь близько 600 учасників [2].

Серед яскравих виступів жіночого хору у 2018 p. згадаємо участь у традиційному Шевченківському концерті (ТНПУ ім. В. Гнатюка), де був репрезентований "Заповіт” Г. Хоткевича за участю зведеного хору та симфонічного оркестру факультету мистецтв; виступ на відзначенні Дня матері у Народному Домі "Перемога", де прозвучали відомі пісні “Де вітер землю голубить” (I. Карабиць, вірші В. Губарця), "Чорнобривці" (В. Верменич, вірші М. Сингаївського) в опрацюванні для жіночого хору Д. Тукала. Успішними стали виступи колективу у концертах до Дня університету, до відзначення ювілею факультету мистецтв “Мистецькі барви 25-ї весни".

Загалом, до репертуару жіночого хору входило більше 50-ти творів - кращих зразків вітчизняної і світової хорової музики. Окремі концертні програми складали твори на Шевченківську тематику, тематичні програми духовної музики, зарубіжної класичної хорової музики, програми з обробок українських народних пісень (від творчості композиторів-класиків - i до сучасних аранжувань), хорові твори відомих сучасних композиторів та ін. [2].

Коротко узагальнимо основний репертуар жіночого хору останнього періоду за окремими блоками. Пріоритетним напрямком стало вивчення та популяризація кращих зразків творів духовної тематики, які формують культурнодуховний світ студентської молоді.

Цей репертуарний пласт представлений творами українських та зарубіжних композиторів різних епох, серед них: А. Вівальді. Кантата “Глорія"(12 ч.); В.-А.Моцарт. "Quitollis"; Д. Бортнянський. Хоровий концерт № 3 (I ч.); М. Лисенко. Хоровий концерт "Камо піду от лиця твого, Господи"; М. Леонтович. "Світло тихе” (Фрагмент з Вечірньої); О. Кошиць. "Хваліте Господа 3 небес" (фрагмент 3 Літургіï); П. Чесноков. “Душе моя” (фрагмент 3 канону А. Крицького); Б. Фільц. “Богородице Діво”; Р. Твардовський. “Алилуя”. У цьому навчальному році до репертуару увійшли 2 нові твори П. Янчака: "Kirie eleison", "De profundis clavami" [2].

Як зазначалося вище, вагомою складовою репертуару хору $є$ значне число обробок народних пісень a capella, серед яких: О. Кошиць. “Час додому, час"; М. Леонтович. “Ой сивая зозуленька"; К. Стеценко. “Ой на горі сніг біленький”; П. Козицький. “Ой у полі-полі”; М. Колесса. "Весільні пісні”; Є. Козак. “Ой, дівчино, шумить гай” та “Якби мені черевики”.

Цікавими у музикознавчомута інтерпретаційному плані є сучасні обробки, серед яких: В. Зубицький. “Співаночки” (міні-триптих); Ю. Антків “Дощик”; В. Міхновецький. “Ой полечко, поле”; Г. Давидовський. “Стелися барвінку”; Г. Коваль. “Як я спала на сені”; А. Кушніренко. “Ой вийду я на ту гору”; Л. Кобільник. “Коляда-колядка”; Давидовська-Бедзір. “Ой верше мій, верше” та ін.

Своєрідною "репертуарною візитівкою” хору стала обробка Є. Гунька “Ой піду ж бо я” [3]. У цьому навчальному році до репертуару хору увійшла українська народна пісня “Чом ти не 


\section{КОНЦЕРТНИЙ ТАКОНКУРСНО-ФЕСТИВАЛЬНИЙ НАПРЯМКИ У РОБОТІЗСТУДЕНТСЬКИМИ ХОРОВИМИ КОЛЕКТИВАМИ}

прийшов?” (опрацювання О. Бондаренка). У репертуарному активі хору є також обробки народних пісень у супроводі фортепіано: С. Людкевич. "Гагілка"; А. Дмитрович. “Дощик”; О. Хромушин. "Фантазія на народні теми" та інші [2]

Традиційно для студентських колективів педагогічних і мистецьких вишів України, визначальну роль у репертуарі займає національна хорова класика. Так, репертуарний список жіночого хору прикрашають твори українських композиторів різних епох, серед них: С. Людкевич. "Українська баркарола"; М. Леонтович. 3 хори русалок з опери “На Русалчин Великдень"; П. Козицький. "Все упованіє моє”; Я. Степовий, вірші О. Олеся. “Для всіх ти мертва і смішна”.

Окремий пласт складають цікаві для інтерпретаційної діяльності твори українських композиторів II половини XX - початку XXI ст. Серед них: А. Кос-Анатольський. "Коли заснули сині гори"; Ю. Мейтус. "Утоптала стежечку", Ю. Щуровський. “Дівоча пісня”; І. Ковтун. "Встала весна"; І. Карабиць. "Де вітер землю голубить"; Л. Дичко. "Петрівочка" з камерної кантати № 1; I. Шамо. "Грушечка” та "Веснянка" з фольк-опери "Ятранські ігри"; Ю. Шамо. “Знов весна, і знов надії”.

Ознайомленню із сучасною стилістикою композиторського письма, складним викладом та гармонією сприяє вивчення нових творів із хорового репертуару колективу. Серед них: М. Телюк. "Ранок”, “Мрії”; В. Герасимчук. “До тебе, Україно”, “Місяць яснесенький”, "Соловейковий спів навесні" з циклу “Сім струн” на сл. Л. Українки; А. Муха. “Зелений явір”; Д. Скоропад. "Місяченьку”; П. Добровольський, сл. В.Сосюри. “Любіть Україну” та ін. У цьому навчальному році репертуар хору поповнив маловідомий широкому загалу твір “Село" (Я. Барнич, вірші Т. Шевченка) [2].

Відповідно до навчальних програм, до укомплектування програм тематичних підбірок, значне місце у репертуарі жіночого хору відводиться творам зарубіжної класики. Серед них: Р. Шуман. "Цигани”; Ф. Шуберт. “Аве Марія”, Й. Штраус. "Весна” (Віденський вальс) (вірші М. Гунько); хорові уривки 3 опер О. Бородіна, М. Мусоргського, П. Чайковського, відомі твори “Яблоня” П. Чеснокова, “Весение воды” С. Рахманінова та ін. Цього навчального року до репертуару хору увійшов твір “Тік-так” О. Лассо [2].

Популярністю у студентів та слухачів концертних виступів жіночого хору користуються переклади композицій зарубіжних митців. Це, для прикладу: Дж. Гершвін. "Радість-ритм"; О. Петерсон. "Гімн свободі"; Дж. Керн. “Дим" 3 мюзиклу "Роберта"; Дж. Кендер. "And All That Jazz" з мюзиклу "Чікаго"; Р. Артман. "Бах і рок"; С. Родрігес. "Кумпарсіта" та ін.

Серед сучасних композицій назвемо такі твори, які $\epsilon$ у постійному репертуарі колективу: М. Парцхаладзе. Вокаліз "У Вечного огня", “Озеро”; В. Шаӥнський “Весела фуга”; Ю. Фалик, вірші тернопільського поета О. Германа. “Осінній малюнок” та ін. Особливе зацікавлення у студентів викликають хорові переклади популярних пісень, для прикладу пісня В. Івасюка в обробці 3. Куркової “Балада про мальви” [2].

Цікавою новітньою формою репрезентації хорових творів стало створення т. зв. “хоровохореографічних композицій” (виконання хорових творів із активним використанням хореографічного компоненту). Прикладом $€$ “And All That Jazz" (музика з мюзиклу "Чікаго" Дж. Кендера), вперше представлена на концерті до Дня університету (2016); “Фантазія на теми українських народних пісень” О. Хромушина (2017); “Весела фуга” В. Шаїнського, репрезентована на концерті до Дня факультету та до Дня музики (2017). У цих репрезентаціях значна увага приділяється нами створенню сценічного образу, стилістиці одягу та ін. Успіху цих постановок завдячуємо викладачу-хореографу Л. Щур [2]. Цей досвід студенти активно використовують і впродовж проходження педагогічних практик, підготовки курсових і магістерських творчих робіт.

Хор є постійним учасником щорічних Шевченківських святкувань, інших мистецьких подій, які організовує факультет мистецтв та виховний відділ ТНПУ ім. В. Гнатюка. Ця діяльність жіночого хору відзначена, зокрема, Управлінням освіти та науки Тернопільської державної адміністрації Дипломом першого ступеня як переможця творчих звітів ВН3 I - IV рівнів акредитації під гаслом "Україна - єдина родина" (2017 р.) [2].

Висновки. Можемо стверджувати, що колектив жіночого хору університету перебуває у постійному творчому оновленні та зростанні. Вважаємо, що саме поєднання навчальної, концертної, фестивальної практики забезпечує цілісність процесу фахової підготовки учасників та майбутніх керівників хорових колективів. Ефективності процесу сприяє і відповідний різножанровий і різностильовий репертуарний матеріал, який повинен включати шедеври європейської і світової хорової музики, високохудожні зразки вітчизняної класичної 
музики, невичерпні багатства української пісенної народної творчості, зразки сучасного хорового письма, цікавих перекладів та аранжувань сучасної популярної музики.

Усе це разом сприяє розвитку і популяризації мистецтва вокально-хорового співу, української співацької традиції, яка пов'язує драматичне і героїчне минуле нашого народу, стверджує впевненість у перемогах над викликами сьогодення, дозволяє упевнено будувати майбутнє України.

\section{ЛІТЕРАТУРА}

1. Іздепська-Новіцька М. Конкурс солістіввокалістів та хорових колективів “Соломія" у культурно-мистецькому житті Тернопільщини. Стратегії підвищення якості мистецької освіти в контексті змін сучасного соціокультурного простору. Матеріали і тези I Міжнародної науковопрактичної конференції (Одеса 13-14 жовтня 2017 р.). Одеса, 2017. С. 22-26.

2. Іздепська-Новіцька М. Жіночий хор факультету мистецтв. Мистецька діяльність у сучасному соціокультурному просторі (25-літній творчий внесок факультету мистецтв Тернопільського національного педагогічного університету ім. В. Гнатюка): колективна монографія / за заг. ред. Б.О. Водяного та ін. Тернопіль, 2018. С. $80-95$.

3. Канюка А.Г., Проців Л.Й. Творча діяльність диригентського класу Свгена Гунька. Мистецька діяльність у сучасному соціокультурному просторі (25-літній творчий внесок факультету мистецтв Тернопільського національного педагогічного університету ім. В. Гнатюка): колективна монографія / за заг. ред. Б.О. Водяного та ін. - Тернопіль, 2018. С. 315 - 322.

4. Місько Г.С., Смоляк О.С. Хорова капела “Освіта". Мистецька діяльність у сучасному соціокультурному просторі (25-літній творчий внесок факультету мистецтв Тернопільського національного педагогічного університету ім. В. Гнатюка): колективна монографія / за заг. ред. Б.О. Водяного та ін. Тернопіль, 2018. С. $63-80$.

5. Пронь Н., Гринчук I. Ігор Пронь сподвижник культурно-мистецького життя Тернопільщини. Мистецька діяльність у сучасному соціокультурному просторі (25-літній творчий внесок факультету мистецтв Тернопільського національного педагогічного університету ім. В. Гнатюка): колективна монографія / за заг. ред. Б.О. Водяного та ін. Тернопіль, 2018. С. $330-315$.

\section{REFERENCES}

1. Izdepska-Novitska, M. (2017). Konkurs solistivvokalistiv ta khorovykh kolektyviv "Solomiya" u kulturnomystetskomu zhytti Ternopilshchyny [Competition of soloists and soloists "Solomiya" in the cultural and artistic life of the Ternopil region]. Stratehiyi pidvyshchennya yakosti mystetskoyi osvity $v$ konteksti zmin suchasnoho sotsiokulturnoho prostoru. Materialy $i$ tezy I Mizhnarodnoyi naukovo-praktychnoyi konferentsiyi (Odesa 13-14 zhovtnya 2017 r.). Strategies for raising the quality of artistic education in the context of changes in contemporary socio-cultural space. Proceedings of the International Scientific and Practical Conference (Odessa, October 13-14, 2017)]. (pp.22-26), Odesa. [in Ukrainian].

2. Izdepska-Novitska, M. (2018). Zhinochyy khor fakultetu mystetstv [Women's Choir of the Faculty of Arts]. Artistic activity in the modern socio-cultural space (the 25-year creative contribution of the Faculty of Arts of the Ternopil National Pedagogical University named after V. Hnatyuk): a collective monograph. Ternopil, pp. 80-95. [in Ukrainian].

3. Kanyuka, A. \& Protsiv, L. (2018). Tvorcha diyalnist dyryhentskoho klasu Yevhena Hunka [Creative activity of conducting class Eugene Hunko]. Artistic activity in the modern socio-cultural space (the 25-year creative contribution of the Faculty of Arts of the Ternopil National Pedagogical University named after V. Hnatyuk): a collective monograph. Ternopil, pp. 315 - 322. [in Ukrainian].

4. Misko, H. \& Smolyak, O. (2018). Khorova kapela "Osvita" [Chapel "Education"]. Artistic activity in the modern socio-cultural space (the 25year creative contribution of the Faculty of Arts of the Ternopil National Pedagogical University named after V. Hnatyuk): a collective monograph. Ternopil, pp. $63-80$. [in Ukrainian].

5. Pron, N. \& Hrynchuk, I. (2018). Ihor Pron spodvyzhnyk kulturno-mystetskoho zhyttya Ternopilshchyny [Igor Pron - associate of cultural and artistic life of Ternopil region]. Artistic activity in the modern socio-cultural space (the 25-year creative contribution of the Faculty of Arts of the Ternopil National Pedagogical University named after V. Hnatyuk): a collective monograph. Ternopil, pp. 330 - 315. [in Ukrainian].

Стаття надійшла до редакції 28.02.2019

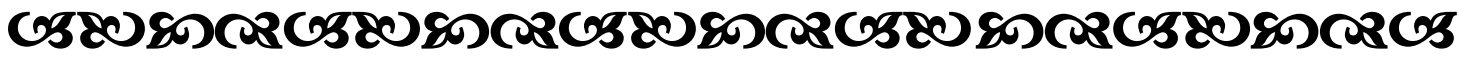

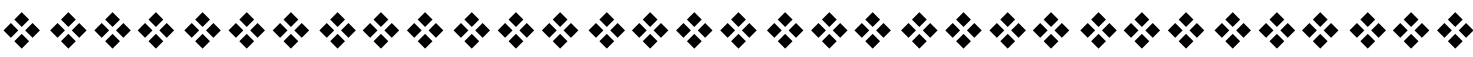

